\title{
DETERMINATION OF THE MOISTURE-DEPENDENT PHYSICAL AND AERODYNAMIC PROPERTIES FOR FENUGREEK SEEDS TO PREDICT THE BEST CLEANING SYSTEM
}

\author{
H. H. Mohamed*
}

\begin{abstract}
Some physical and aerodynamic properties of fenugreek seeds were measured as a function of moisture content. The data obtained during experiments showed that there were significant deviations in all of the measured parameters for fenugreek seeds. Increasing seeds moisture content from 13 to 27\%(w.b) resulted in increasing the average length, width, thickness, geometric mean diameter, seed volume and thousand seed weight from 4.29 to $5.13 \mathrm{~mm}, 2.97$ to $3.11 \mathrm{~mm}, 1.87$ to $2 \mathrm{~mm}, 2.87$ to $3.17 \mathrm{~mm}, 19.5$ to $26.6 \mathrm{~mm}^{3}$ and 15.6 to $19.2 \mathrm{~g}$ respectively, while sphericity and bulk density decreased from 67.4 to $61.9 \%$ and from 800.6 to $722.2 \mathrm{~kg} / \mathrm{m}^{3}$ respectively. The static coefficients of friction on wire mesh screen, the terminal velocity and the projected area increased from 0.43 to 0.56 , from 6.6 to $8.11 \mathrm{~m} / \mathrm{s}$ and from 0.11 to $0.14 \mathrm{~cm}^{2}$ respectively at the above mentioned moisture content range. A computer program was developed to calculate the number of cleaning stages according to the physical and aerodynamic properties of fenugreek seeds to maximize cleanliness, MOG rejected, separating efficiency and minimize seed loss.
\end{abstract}

Keywords: Aerodynamic properties, fenugreek seeds, density, terminal

\section{INTRODUCTION}

lenugreek (Trigonella foenum-graceum L.) is an annual herb of
leguminosea, is being used as spice crop in the entire world. It is
used as medicine industry, cosmetic material and food flavor. Fenugreek is known as Greek hay which native to Southern Europe, the Mediterranean region and Western Asia but now is grown as a spice in most parts of the world. The Major fenugreek-producing countries are India, Iran, Egypt and China.

\footnotetext{
*Ag. Eng. Dept., Fac of Agric. Saba Basha, Alexandria Univ., Egypt. Email: haitham_egypt76@yahoo.com
} 
The seeds and leaves have bitter taste and strong odor which have been used to reduce blood sugar and lower blood cholesterol. Physical and aerodynamic properties of fenugreek seeds are very important factors affecting cleaning, grading, handling and processing machines. El-Nakib and Abdel-Galil (2008) determined physical and mechanical properties of fenugreek seeds to develop and evaluate rotating screen separator for grading and cleaning fenugreek seeds. The separating efficiency increased by increasing the angular velocity of the horizontal cylindrical sieve (about 7\% less than the critical velocity). The optimum parameters for separating fenugreek seeds under the specific conditions of this study were screen speed of 140 r.p.m, feed rate of $5 \mathrm{~kg} / \mathrm{h}$ and screen slope of $0^{\circ}$. Hanna (2003) reported that after threshing medicinal and aromatic plants, the seeds usually consist of heterogeneous mix of stems, leaves, chaff, (MOG) and seeds of various size and quality. The traditional method for cleaning medicinal and aromatic seeds is by tossing the mixture of seeds and chaff through a current of air so that the light material other than grain (MOG) will be blown away from the heavier seeds. In this method the loss will be high about $30 \%$ and cleanliness will be low. Altuntas et al. (2005) evaluated some physical properties of fenugreek seeds as a function of moisture content to optimize the equipment design for harvesting, handling, storing and other processes of fenugreek seed. The average length, width, thickness, geometric mean diameter and unit mass of the seed ranged from 4.01 to $4.19 \mathrm{~mm}, 2.35$ to $2.61 \mathrm{~mm}, 1.49$ to $1.74 \mathrm{~mm}, 2.40$ to $2.66 \mathrm{~mm}$ and 0.0157 to $0.0164 \mathrm{~g}$ as moisture content increased from $8.9 \%$ to $20.1 \%$ (d.b). respectively. This research was carried out (1) To study the effect of seeds moisture content on the physical and aerodynamic properties of fenugreek seeds such as length, width, thickness, geometric mean diameter, projected area, sphericity, thousand seed weight, bulk density, seed volume, coefficient of friction and terminal velocity. (2) To develop a computer program for determining the number of cleaning stage for fenugreek seeds and to calculate Seed loss, MOG rejected, Cleanliness, Separating efficiency and Machine effectiveness after all cleaning stages.

\section{MATERIAL AND METHODS}

Fenugreek seeds used in these experiments were collected after manual harvesting and threshing in Tanta, Egypt at moisture content of $13 \%$ (wb). The moisture content of the seeds was estimated by oven drying at 
$105 \pm 1{ }^{\circ} \mathrm{C}$ for $24 \mathrm{~h}$ (Suthar \& Das, 1996). The desired moisture levels (16, 20 and 27\%) were equipped by adding calculated amounts of water in samples and then putting in polyethylene bags. The samples were left in a refrigerator for 7 day at $5{ }^{\circ} \mathrm{C}$. The seed length, width and thickness were determined using a vernier caliper with accuracy of $0.1 \mathrm{~mm}$. Sample of 100 randomly selected seeds from each of the four moisture levels were used to determine the grain dimensions. The seed geometric mean diameter $(\mathrm{Dg})$ in $\mathrm{mm}$ and sphericity $(\mathrm{Sp})$ in percent were calculated using the following relationships given by (Ndirika and Oyeleke, 2005).

$$
\begin{aligned}
\mathrm{Dg} & =\sqrt[3]{\mathrm{L} \times \mathrm{W} \times \mathrm{T}} \\
\mathrm{Sp} & =((\sqrt[3]{\mathrm{L} \times \mathrm{W} \times \mathrm{T}}) / \mathrm{L}) \times 100
\end{aligned}
$$

Where: $\mathrm{L}, \mathrm{W}$ and $\mathrm{T}$ are length, width and thickness of the seed in $\mathrm{mm}$ respectively.

The volume of fenugreek seeds in $\mathrm{mm}^{3}$ was determined from the following relationship given by özarslan (2002):

$$
\mathrm{V}=\mathrm{m} / \rho_{\mathbf{k}}
$$

Where: $\mathrm{V}, \mathrm{m}$ and $\rho_{\mathrm{k}}$ are seed volume in $\mathrm{m}^{3}$, seed unit mass in $\mathrm{Kg}$ and the kernel density in $\mathrm{Kg} / \mathrm{m}^{3}$ respectively.

The thousand seed Weight was determined by an electronic balance with an accuracy of $0.001 \mathrm{~g}$. Ten samples of 1000 seeds were counted by hand to determine the thousand kernel weight. The terminal velocity of fenugreek seeds was measured by using the terminal velocity apparatus as shown in Fig.(1). which consists of a $2 \mathrm{~m}$ vertical transparent plexi glass tube with diameter of $192.3 \mathrm{~mm}$. The air was provided to the vertical tube to suspend the seed in an air stream by a

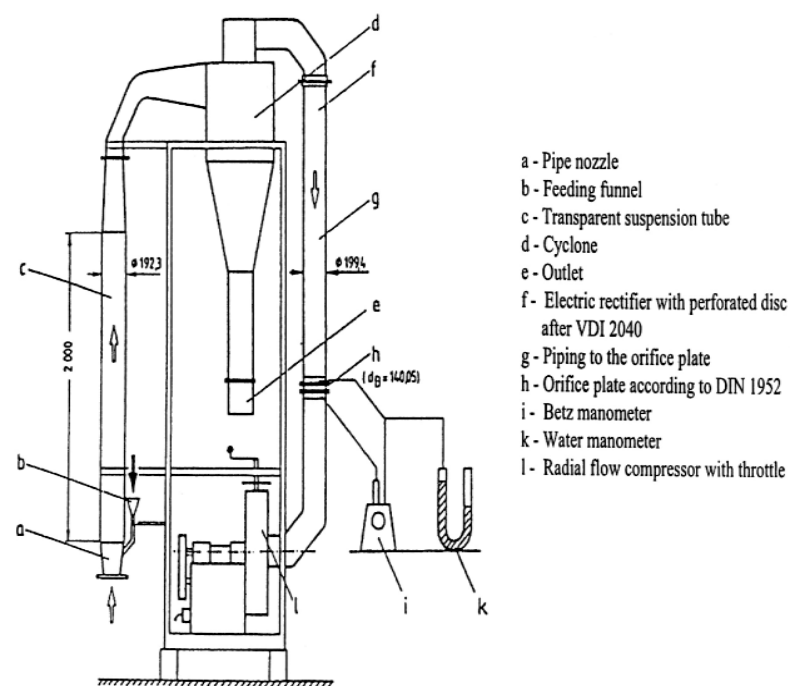

Fig. (1): Terminal velocity apparatus (El-Sayed et al; 2001). suction blower fan powered by an electric motor. The mean air velocity in the transparent tube was determined by an electronic manometer at a measuring orifice. 
The test was carried out by putting $100 \mathrm{~g}$ sample into the feeding funnel. The air velocity was increased by opening the fan throttle manually. Each air velocity was left two minutes until the particles appear through the transparent tube which was carried to outlet through the cyclone. The particles were collected to determine the separated seeds, (\%) at each air velocity. The test was continued until no material remaining in the pipe nozzle (El-Sayed et al; 2001).

The bulk density of the seeds was determined by using bulk density cylinder. Ten samples were selected at each moisture content level to determine the bulk density. The seeds were weighted and packed into cylinder with known volume (Beck, 1991). The bulk density of the seeds was calculated as follows:

$$
\mathrm{Bd}=\frac{\mathrm{Sw}}{\mathrm{Sv}}
$$

Where: $\mathrm{Bd}, \mathrm{Sw}$ and $\mathrm{Sv}$ are the bulk density in $\mathrm{Kg} / \mathrm{m}^{3}$, seed weight in $\mathrm{Kg}$ and seed volume in $\mathrm{m}^{3}$

The coefficient of friction of the seeds on wire mesh screen was determined by using friction angle measuring device which consists of sliding surface and optical cell. Samples of 50 randomly selected seeds of each moisture content level were selected to determine the friction angle. A seed was placed between light source and receiver of an optical cell so that the receiver didn't receive any light and the sliding surface was automatically tended vertically until the kernel just start to slide. At this moment the receiver received light from the light source and the sliding surface was stopped at known angle (Beck, 1991).

The coefficient of friction of the material was determined as follows:

$$
\mu=\tan \varnothing
$$

Where: $\mu$ and $\varnothing$ are the coefficient of friction and the angle between the sliding surface and the horizontal level in degrees

The projected area of the whole grains was determined by using (Image Processing and Pattern Recognition System). After calibrating the system a sample of 100 seeds was placed on the white surface under Kodak color camera which takes digital image. Software Image Editor analyzed the digital image to calculate surface area of the seed. 


\section{RESULTS AND DISCUSSION}

The data obtained during the measurements showed that there were deviations in all of the measured parameters for fenugreek seeds, the most deviation was found for projected area at moisture content of $13 \%$ with coefficient of variation of $14.16 \%$ while the least deviation was the thousand seed weight at moisture content of $16 \%$ with coefficient of variation of $0.14 \%$ as shown in table 1 .

\section{1- Dimensions}

Increasing seeds moisture content from 13 to $27 \%$ (w.b) resulted in increasing the average length, width, thickness and geometric mean diameter, mm from 4.29 to $5.13 \mathrm{~mm}, 2.97$ to $3.11 \mathrm{~mm}, 1.87$ to $2 \mathrm{~mm}$ and 2.87 to 3.17 , $\mathrm{mm}$ respectively as shown in Fig. (2).The relationship between seeds moisture content and each of average length, width, thickness and geometric mean diameter can be represented by linear regression equations: $\quad(13 \leq \mathrm{M} . \mathrm{C} . \leq 27 \%)$

$$
\begin{aligned}
& \mathrm{L}=0.059 M+3.50\left(\mathrm{R}^{2}=0.99\right)(6) \quad \mathrm{W}=0.009 M+2.85\left(\mathrm{R}^{2}=0.98\right) \\
& \mathrm{T}=0.008 M+1.76\left(\mathrm{R}^{2}=0.97\right)(7) \quad \mathrm{G}=0.020 M+2.61 \quad\left(\mathrm{R}^{2}=0.99\right)
\end{aligned}
$$

where: $\mathrm{L}, \mathrm{W}, \mathrm{T}, \mathrm{G}$ and $M$ are length, width, thickness, geometric mean diameter in $\mathrm{mm}$ and moisture content, \% respectively.

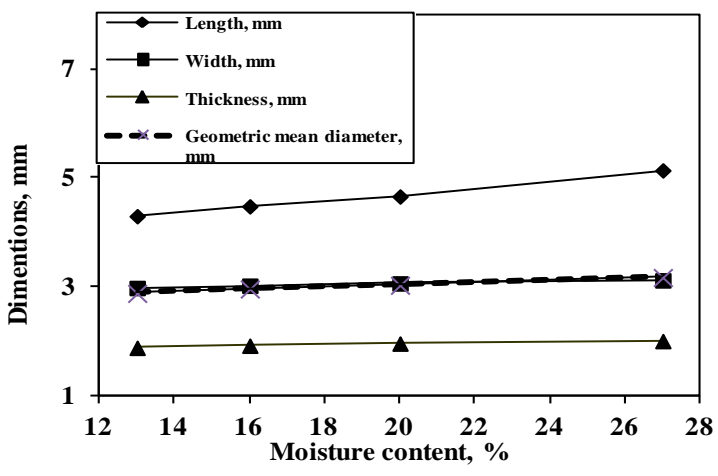

Fig. (2): Effect of moisture content on average length, width, thickness and geometric mean diameter.

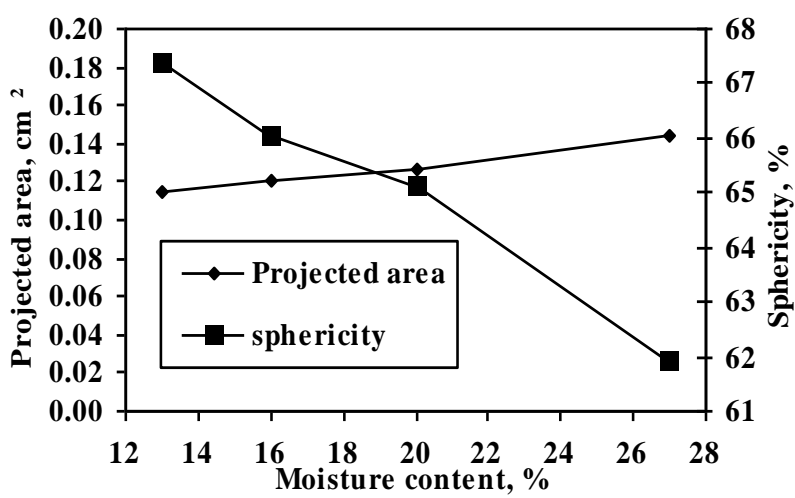

Fig. (3): Effect of moisture content on average Projected area and sphericity.

\section{2- Projected area (Sa)}

Increasing seeds moisture content from 13 to $27 \%$ (w.b) resulted in increasing the average projected area linearly from 0.114 to $0.144 \mathrm{~cm}^{2}$ as shown in Fig. (3). The linear relationship can be represented by the regression equation: 


$$
\mathrm{Sa}=0.0021 M+0.086 \quad\left(\mathrm{R}^{2}=0.98\right) \quad(13 \leq \mathrm{M} . \mathrm{C} . \leq 27 \%)
$$

A mathematical equation was concluded from the measured seed length and width to estimate projected area of the seed:

$\mathrm{Sa}=(0.9 \mathrm{~L} . \mathrm{W}) \quad(13 \leq \mathrm{M} . \mathrm{C} . \leq 27 \%)$

where : $\mathrm{Sa}, \mathrm{L}$ and $\mathrm{W}$ are surface area, length and width respectively.

\section{3- Coefficient of friction $(\mu)$}

Increasing seeds moisture content from 13 to $27 \%$ (w.b) resulted in increasing the average coefficient of friction on wire mesh screen linearly from 0.43 to 0.56 as shown in Fig. (4). The relationship can be represented by linear regression equation:

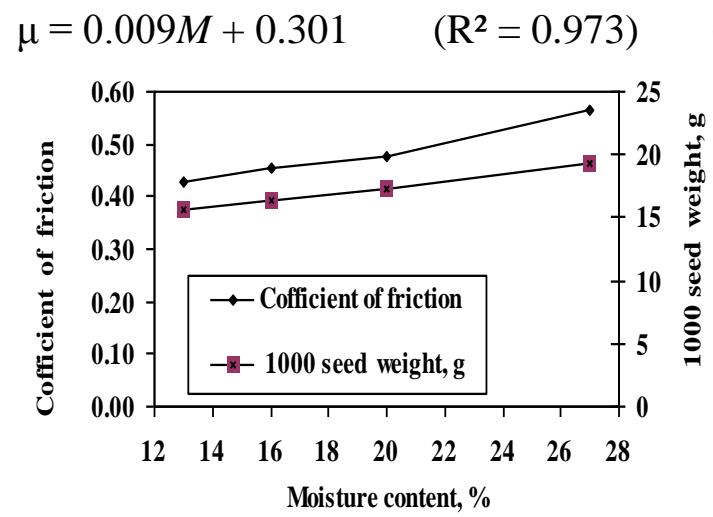

Fig. (4): Effect of moisture content on average coefficient of friction and 1000 seed weight.
$(13 \leq$ M.C. $\leq 27 \%) \quad(12)$

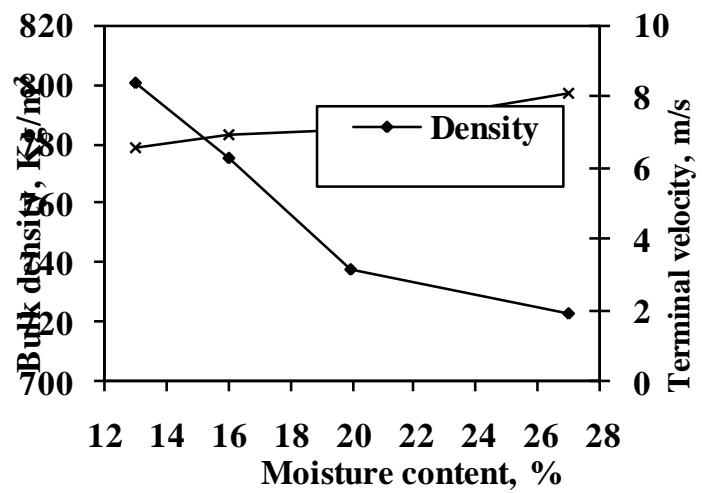

Fig. (5):Effect of moisture content on average bulk density and terminal velocity.

\section{4- Thousand seed weight (TSW)}

Increasing seeds moisture content from 13 to $27 \%$ (wb) resulted in increasing the average thousand seed weight from 15.62 to 19.22 , g as shown in Fig. (4). The relationship can be represented by linear regression equation:

$\mathrm{TSW}=0.253 M+12.32 \quad\left(\mathrm{R}^{2}=0.99\right) \quad(13 \leq \mathrm{M} . \mathrm{C} . \leq 27 \%)$

\section{5- Sphericity $\left(\mathrm{S}_{\mathrm{p}}\right)$}

Increasing seeds moisture content from 13 to $27 \%$ (wb) resulted in decreasing seeds sphericity from 67.4 to $61.9 \%$ as shown in Fig. (3). The relationship can be represented by linear regression equation:

$$
\mathrm{S}_{\mathrm{p}}=-0.38 M+72.371 \quad\left(\mathrm{R}^{2}=0.98\right) \quad(13 \leq \mathrm{M} . \mathrm{C} . \leq 27 \%)
$$

\section{6- Bulk density $\left(B_{d}\right)$}


Increasing seeds moisture content from 13 to $27 \%$ (w.b) resulted in decreasing the average bulk density linearly from 800.6 to $722.2 \mathrm{~kg} / \mathrm{m}^{3}$ as shown in Fig. (5). The relationship can be represented by linear regression equation:

$$
\mathrm{B}_{\mathrm{d}}=-5.58 M+865.26 \quad\left(\mathrm{R}^{2}=0.90\right) \quad(13 \leq \mathrm{M} . \mathrm{C} . \leq 27 \%)
$$

7- Terminal velocity $\left(T_{v}\right)$

Increasing seeds moisture content from 13 to $27 \%$ (w.b) resulted in increasing the average terminal velocity linearly from 6.6 to $8.11 \mathrm{~m} / \mathrm{s}$ as shown in Fig.

(5). The relationship can be represented by linear regression equation: $\mathrm{T}_{\mathrm{v}}=$ $0.10 M+5.19 \quad\left(\mathrm{R}^{2}=0.96\right) \quad(13 \leq \mathrm{M} . \mathrm{C} . \leq 27 \%)$

Table 1. Physical and aerodynamic properties of Fenugreek seeds (Trigonella foenum-graceum L.).

\begin{tabular}{|c|c|c|c|c|c|c|c|c|c|c|}
\hline \multirow{2}{*}{ Parameter } & \multicolumn{5}{|c|}{ Moisture content $13 \%$} & \multicolumn{5}{|c|}{ Moisture content $16 \%$} \\
\hline & Aver & SD & $\mathrm{CV}, \%$ & Min & Max & Aver & SD & $\mathrm{CV}, \%$ & Min & Max \\
\hline Length, mm & 4.29 & 0.48 & 11.26 & 3.4 & 5.5 & 4.65 & 0.36 & 7.82 & 4.11 & 4.9 \\
\hline Width, mm & 2.97 & 0.24 & 7.96 & .5 & 3.5 & 3.05 & 0.24 & 7.9 & 2.9 & 3.4 \\
\hline Thickness, mm & 1.87 & 0.16 & 8.64 & 1.5 & 2.2 & 1.94 & 0.17 & 8.53 & 1.8 & 2.05 \\
\hline Geo mean diam, mm & 2.87 & 0.18 & 6.3 & 2.47 & 3.29 & 3.02 & 0.17 & 5.73 & 2.91 & 3.12 \\
\hline Sphericity, $\%$ & 67.41 & 5.13 & 7.62 & 58.12 & 78.96 & 64.82 & 4.6 & 7.1 & 62.8 & 67.9 \\
\hline Coefficient of friction & 0.43 & 0.05 & 12.31 & 0.41 & 0.44 & 0.45 & 0.05 & 11.34 & 0.42 & 0.46 \\
\hline Projected area, $\mathrm{cm}^{r}$ & 0.11 & 0.02 & 14.16 & 0.08 & 0.15 & 0.13 & 0.02 & 12.91 & 0.121 & 0.132 \\
\hline Terminal velocity, $\mathrm{m} / \mathrm{s}$ & 6.6 & 0.67 & 10.08 & 5.20 & 8.40 & 6.94 & 0.58 & 8.36 & 5.70 & 8.00 \\
\hline Thousand seed weight, $\mathrm{g}$ & 15.68 & 0.03 & 0.21 & 15.20 & 16.50 & 16.36 & 0.02 & 0.14 & 16.10 & 16.66 \\
\hline Density $\mathrm{kg} / \mathrm{m}^{3}$ & 800.6 & 0.94 & 1.18 & 749 & 801 & 775.6 & 2.03 & 2.62 & 773.3 & 776.3 \\
\hline Volume, $\mathrm{mm}^{3}$ & 19.59 & 0.98 & 5 & 19.1 & 20.14 & 21.09 & 2.05 & 9.73 & 20.1 & 22.21 \\
\hline \multirow{2}{*}{ Parameter } & \multicolumn{5}{|c|}{ Moisture content $20 \%$} & \multicolumn{5}{|c|}{ Moisture content $27 \%$} \\
\hline & Aver & SD & $\mathrm{CV}, \%$ & Min & Max & Aver & SD & $\mathrm{CV}, \%$ & Min & Max \\
\hline Length, mm & 4.69 & 0.42 & 8.97 & 4 & 5.6 & 5.13 & 0.4 & 7.84 & 4.3 & 6 \\
\hline Width, mm & 3.06 & 0.23 & 7.45 & 2.5 & 3.5 & 3.11 & 0.26 & 8.28 & 2.5 & 3.7 \\
\hline Thickness, mm & 1.95 & 0.17 & 8.81 & 1.6 & 2.3 & 2 & 0.16 & 8.16 & 1.7 & 2.4 \\
\hline Geo mean diam ,mm & 3.02 & 0.17 & 5.56 & 2.71 & 3.34 & 3.17 & 0.17 & 5.32 & 2.79 & 3.61 \\
\hline Sphericity, $\%$ & 65.13 & 3.86 & 5.92 & $\mathbf{5 8 . 4 7}$ & 74.38 & 61.93 & 4.81 & 7.76 & 53.49 & 78.31 \\
\hline Coefficient of friction & 0.48 & 0.05 & 10.36 & 0.47 & 0.49 & 0.57 & 0.08 & 13.83 & 0.55 & 0.58 \\
\hline Projected area, $\mathrm{cm}^{r}$ & 0.13 & 0.02 & 12.43 & 0.094 & 0.157 & 0.14 & 0.02 & 12.15 & 0.098 & 0.205 \\
\hline Terminal velocity, $\mathrm{m} / \mathrm{s}$ & 7.11 & 0.69 & 9.71 & 5.70 & 8.30 & 8.11 & 0.81 & 9.93 & 7.00 & 10.00 \\
\hline Thousand seed weight, $\mathrm{g}$ & 17.31 & 0.02 & 0.12 & 17.10 & 17.53 & 19.22 & 0.04 & 0.22 & 18.70 & 19.69 \\
\hline Density $\mathrm{kg} / \mathrm{m}^{3}$ & 737.8 & 1.53 & 2.07 & 719 & 760 & 722.2 & 1.36 & 1.88 & 702 & 733 \\
\hline Volume, $\mathrm{mm}^{3}$ & 23.46 & 1.55 & 6.6 & 23.15 & 24.32 & 26.61 & 1.4 & 5.25 & 26.19 & 26.95 \\
\hline
\end{tabular}




\section{8- Volume (V)}

Increasing seeds moisture content from 13 to $27 \%$ (w.b) resulted in increasing seed volume linearly from 19.59 to $26.61 \mathrm{~mm}^{3}$ which can be represented by linear regression equation:

$\mathrm{V}=0.505 \mathrm{M}+13.09 \quad\left(\mathrm{R}^{2}=0.996\right) \quad(13 \leq \mathrm{M} . \mathrm{C} . \leq 27 \%)$

A mathematical equation was concluded from the measured seed length, width and thickness to estimate seed volume:

$$
\mathrm{V}=0.92(\text { L.W.T }) \quad(13 \leq \mathrm{M} . \mathrm{C} . \leq 27 \%)
$$

where : $\mathrm{V}, \mathrm{L}, \mathrm{W}$ and $\mathrm{T}$ are seed volume in $\mathrm{mm}^{3}$, length, width and thickness in $\mathrm{mm}$ respectively. According to the measured physical and aerodynamic properties of Fenugreek seeds at different moisture content the minimum values of seed dimensions, volume, thousand seed weight, terminal velocity and coefficient of friction were at moisture content of 13 $\%$ (wb) as shown in Table (1). Since it is easier to clean, grade and handle seeds at smallest volume, weight and air velocity. Besides, at minimum moisture content, seeds damage does not occur fast as in higher moisture contents. The frequency distribution curves for thickness of seeds and MOG were used to determine the best thickness to separate big MOG from the seed as shown in Fig.(7).

The frequency distribution curves for width of seeds and MOG were used to determine the best width to separate to separate small MOG from the seed as shown in Fig.(6). The best thickness and width were used to design upper screen shoe slotted perforation $(2.5 \mathrm{X} 20 \mathrm{~mm})$ and lower

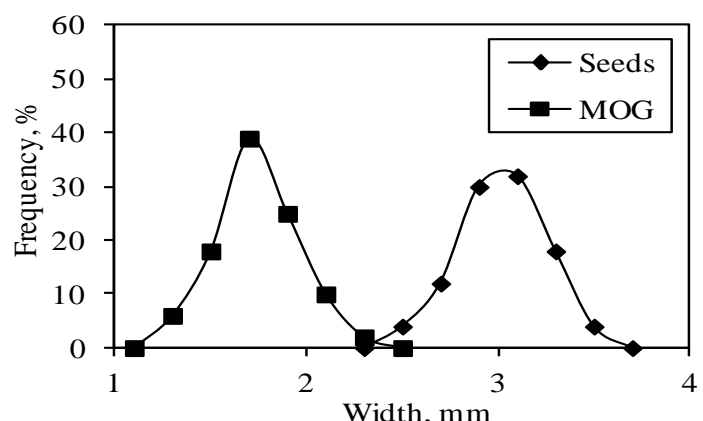

Fig. (6): Frequency distribution curves for width of seeds and MOG.

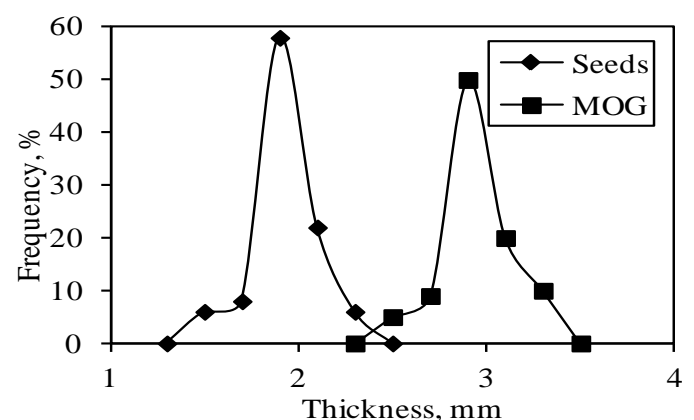

Fig. (7): Frequency distribution curves for thickness of seeds and MOG.

screen shoe round perforation $(2.5 \mathrm{~mm}$ diameter). The frequency distribution curves for terminal velocity of seeds, heavy MOG and light MOG were used to determine the best air velocities to separate heavy 
MOG and light MOG from the seed as shown in Fig .(8). The best high speed air velocity was $8.4 \mathrm{~m} / \mathrm{s}$ which used to separate seeds from heavy MOG. The best low speed air velocity was $5.2 \mathrm{~m} / \mathrm{s}$ which used to separate light MOG from the seed.

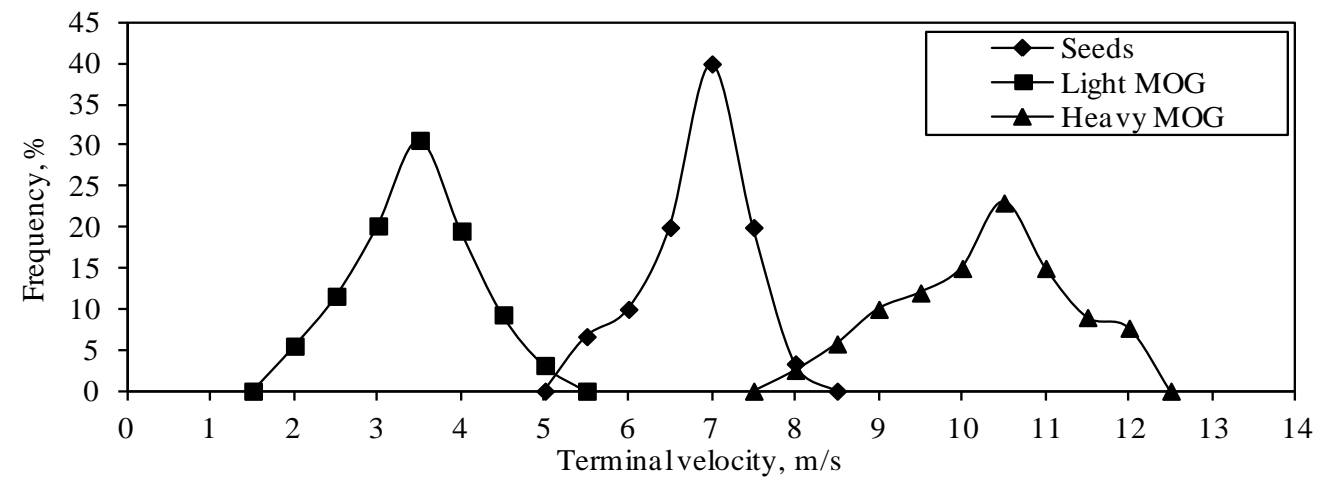

Fig. (8): Frequency distribution curves for terminal velocities of seeds, heavy MOG and light MOG.

\section{9- The computer program:}

A computer program was developed by $\mathrm{C}$ programming language which consists of two steps. The first step was developed to determine the number of cleaning stage for fenugreek seeds. The first cleaning stage consists of aerodynamic separation unit with high speed air velocity. The program compare between the separating efficiency after the first stage and the objected separating efficiency. If separating efficiency after the first stage is higher than the objected separating efficiency, so the first cleaning stage is enough to clean fenugreek seed. If a separating efficiency is lower than the objected separating efficiency, the seed need a second cleaning stage of aerodynamic separation with low speed air velocity. In the second stage the program makes a decision to determine if two stages are enough or extra third stage of slotted openings sieve is needed. In the third stage the program decides if three stages are enough or extra forth stage of round openings sieve is needed. In the forth stage the program decides if the seed need four stages or to repeat them one more time to reach the objected separating efficiency. 2- The second step to calculate Seed loss, MOG rejected, Cleanliness, Separating efficiency and Machine effectiveness after all cleaning stages 


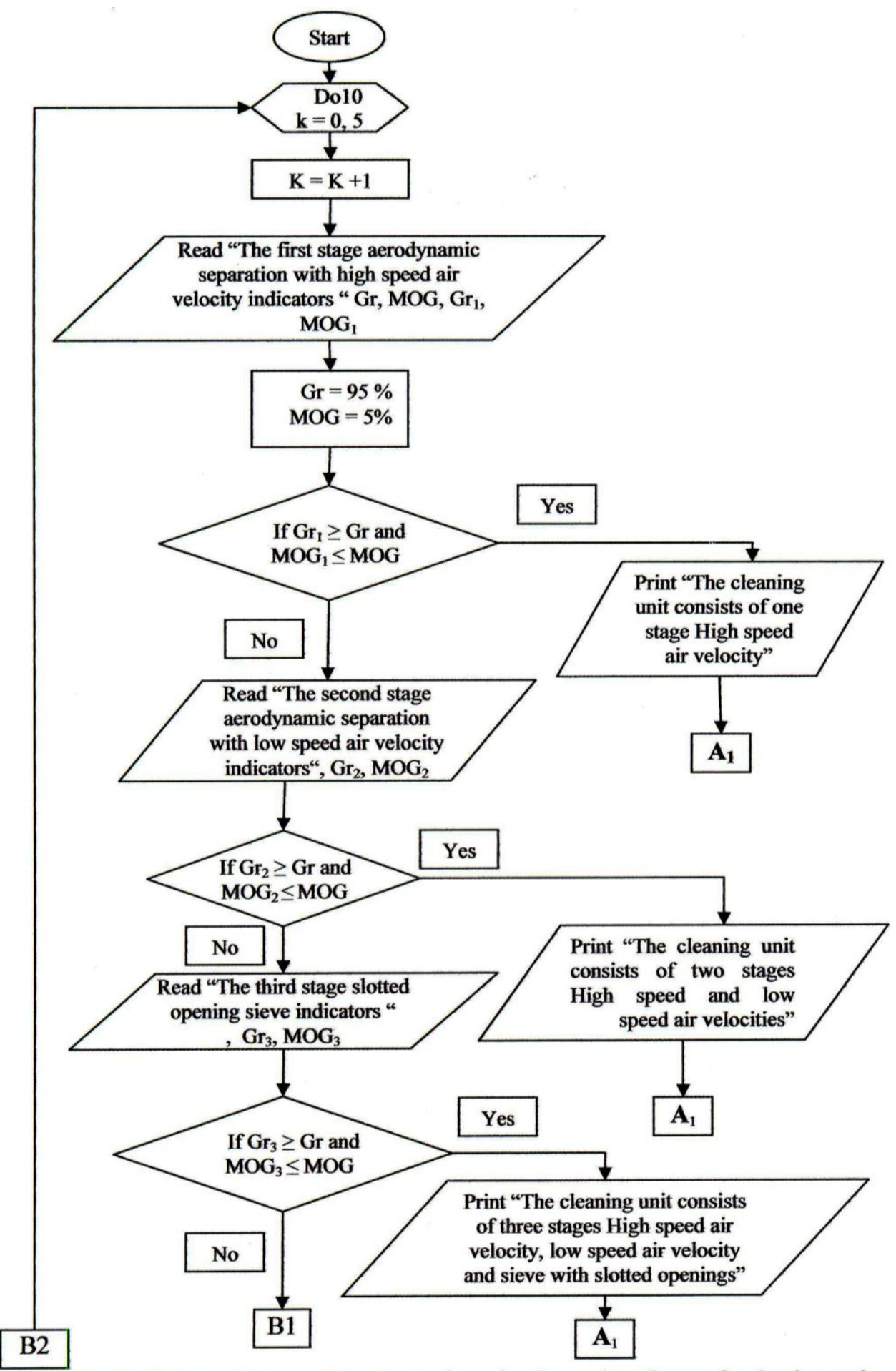

Fig. (9): The first step of program flowchart to determine the number of stages for cleaning seeds. 


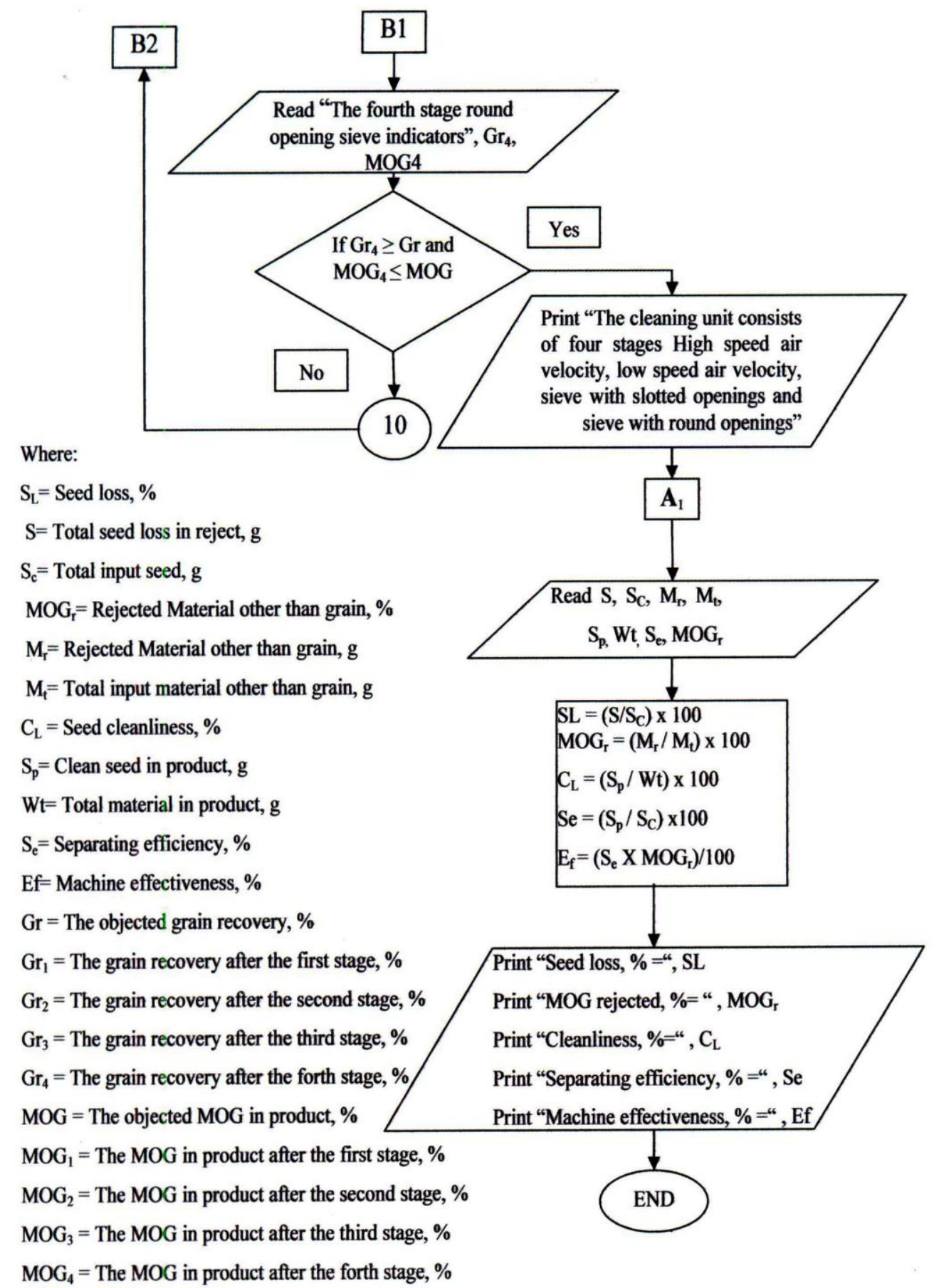

Fig. (10): The second step of program flowchart to determine machine performance. 
The suggested computer program can be used in case of applying a computer numerical control system (CNC) provided by a specific program containing coded alphanumeric data which control the functions and motion stages of the cleaning machine. The CNC system can measure seed and MOG percent after each cleaning stage of the four cleaning stages and convert them to input data required by the suggested program to decide through "if statement" whether the desired cleaning conditions are satisfied or not.

\section{CONCLUSIONS}

The measurements of physical and aerodynamic properties of fenugreek seeds showed that increasing seeds moisture content from 13 to $27 \%$ (w.b) resulted in increasing the average length, width, thickness, geometric mean diameter, seed volume, thousand seed weight, coefficients of friction on wire mesh screen, terminal velocity and projected area while resulted in decreasing sphericity and bulk density. The best moisture content for the seed was $13 \%$ (wb), because the minimum values of seed dimensions, volume, thousand seed weight, terminal velocity and surface area were at this moisture content so that it is easier to clean, to grad and to handle the seed. A suggested computer program was developed to calculate the number of cleaning stages according to the measured physical and aerodynamic properties of fenugreek seeds to maximize cleanliness, MOG rejected, separating efficiency and minimize seed loss. The best cleaning system for fenugreek seeds consists of: 1- Aerodynamic separation unit with air velocity of $8.4 \mathrm{~m} / \mathrm{s}$ to separate the seed from heavy MOG

2- Aerodynamic separation unit with air velocity of $5.2 \mathrm{~m} / \mathrm{s}$ to separate light MOG from the seed 3- Sieve layer 1- upper screen shoe slotted perforation $(2.5 \times 20 \mathrm{~mm})$ to separate big MOG 4- lower screen shoe round perforation $(2.5 \mathrm{~mm}$ diameter) to separate small MOG. 
PROCESS ENGINEERING

\section{REFERENCES}

Altuntas, E., E.özgö and F.Taser, (2004). Some physical properties of fenugreek seeds. Journal of Food Engineering, 71, 37- 43.

Beck, T., 1991. Messverfahren zur Beurteilung des Stoffeigenschaftseinflusses auf die Leistung der Trennprozesse im Mähdrescher.VDI, Reihe:14, No.54.

El-Nakib, A. A. and H. S. Abdel-Galil, (2008). Some parameters affecting cleaning and grading of fenugreek seeds. Misr J. Ag. Eng., Annual Conference:535-554.

El-Sayed., et al., (2001). Characteristic attributes of the peanut for its separation. Int. Agrophysics, 15, 225-230.

Hanna, S. S., (2003). Construction and development of a cleaning unit suitable for medicinal and aromatic seed crops. Ph. D. Dissertation., Fac. of Agri. Tanta University.

Mohamed, H. H., 2004. Mechanization of post-harvesting processes for threshing and seed cleaning of some medicinal and aromatic plants in Egypt. M. Sc. Thesis, Ag. Soil. Dept. Fac. of Agri. Saba-Basha. Alexandria University.

Mohsenin, N. N., (1970). Physical properties of plant and animal materials. New York: Gordon and Breach Science Publisher

Ndirika, V. I. O. and O. O. Oyeleke, (2005). Determination of selected physical properties and their relationships with moisture content for millet. ASABE ISSN 0883-8542, 22(2): 291-297.

özarslan, C., (2002). Some physical properties of cotton seed. Biosystems Engineering, 83(2), 169-174.

Suthar, S. H. and Das, S. K.,(1996). Some physical properties of karingda seeds. Journal of Agricultural Engineering Research, 65(1), 1522. 
PROCESS ENGINEERING

\section{الملخص العربيى \\ دراسة تأثير المحتوي الرطوبي علي الخصائص الطبيعية و الأيروديناميكية

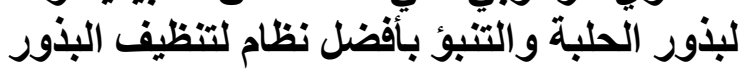

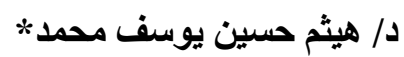

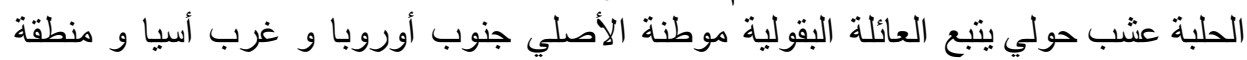

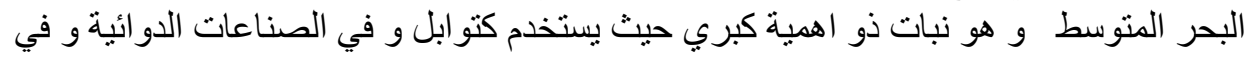
صناعة مستحضر ات التجميل

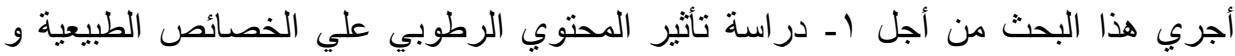

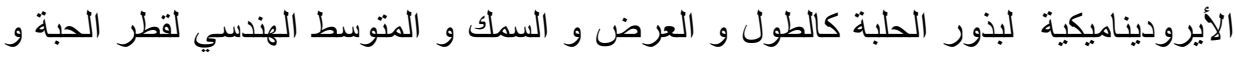

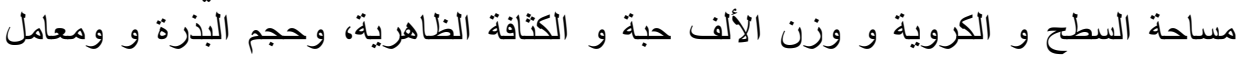

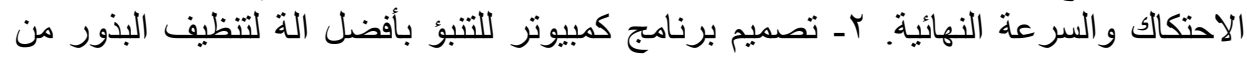

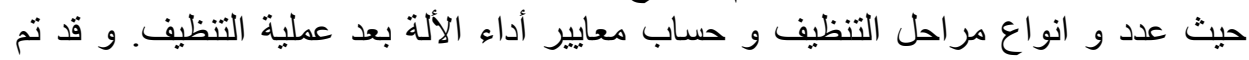

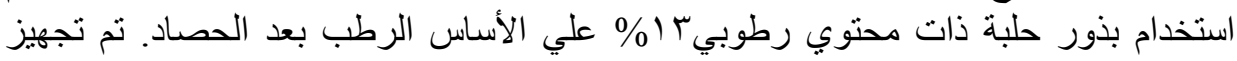

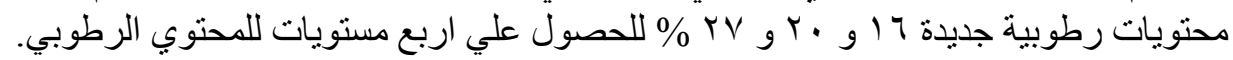

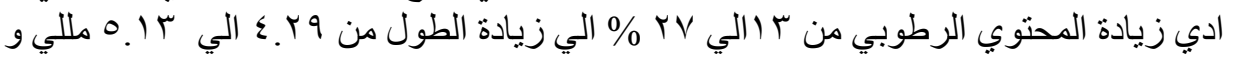

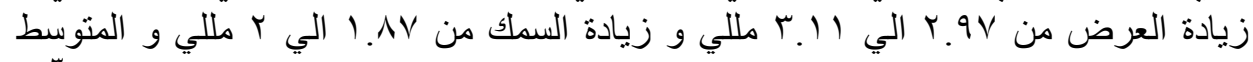

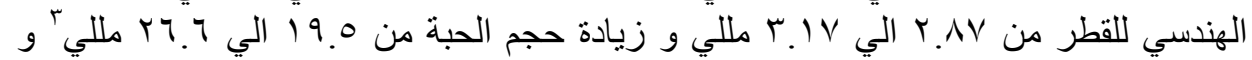

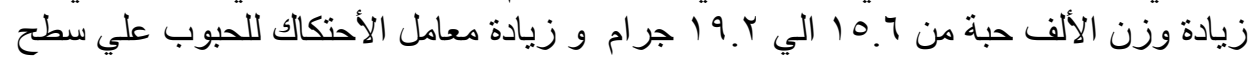

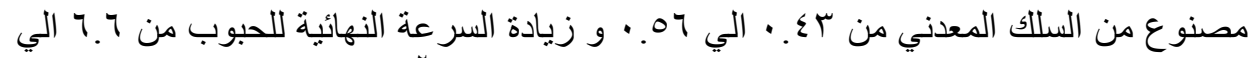

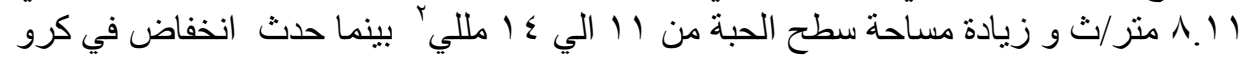

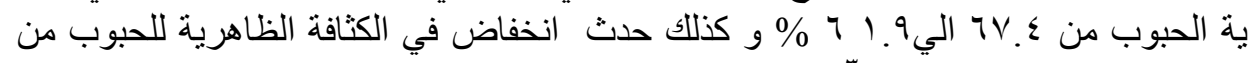

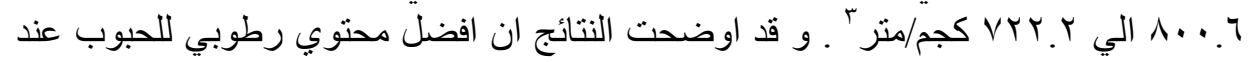

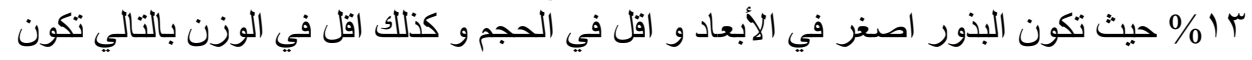

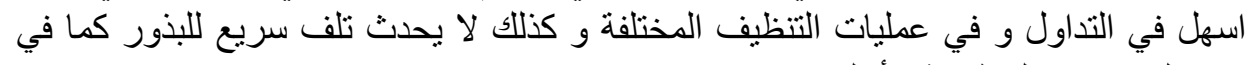
باقي المحتو يات الرطواتية في في الأعلي.

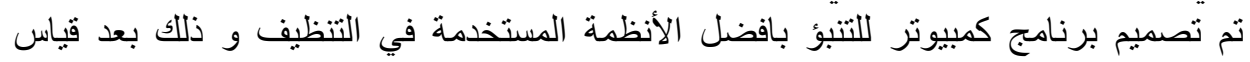

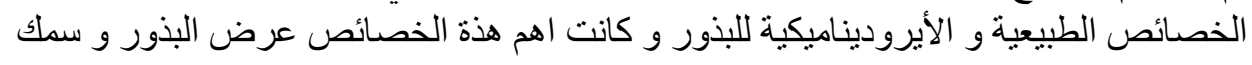
ل البذور و السر عة النهائية للبذور.

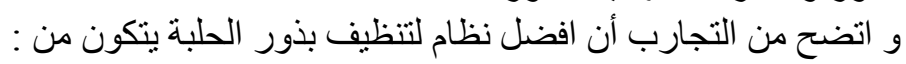

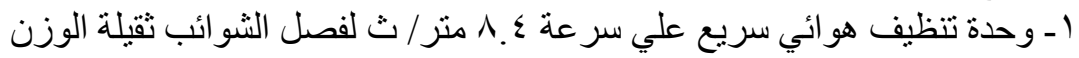

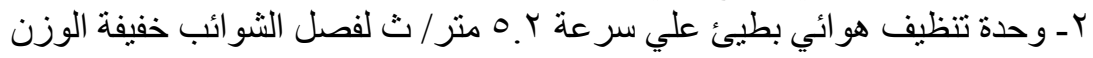

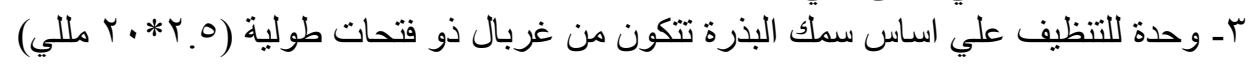

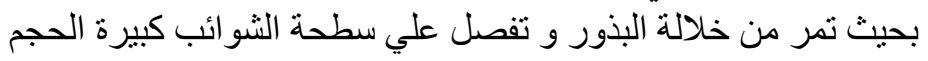

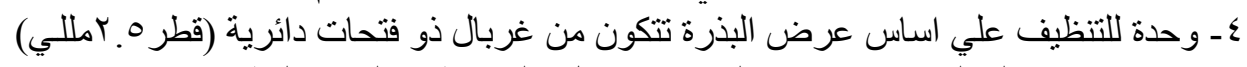
بحيث تمر من خلالة الثيو ائب صغيرة الحجم و تلفصل علي سطحة البذور النظيفة.

مدرس الهندسة الزراعية _ كلية الزراعة ساباباثا - جامعة الأسكندرية 